İş ve İnsan Dergisi | The Journal of Human and Work

Y1l | Year: Ekim | October 2018

Cilt-Sayı | Volume-Issue: 5 (2)

ss I pp: 207-223

doi: 10.18394/iid.364001

e-ISSN 2148-967X

http://dergipark.gov.tr/iid/

Araştırma Makalesi

\title{
Şirketlerin Şeffaflık ve Hesap Verebilirliğinin Vekâlet Kuramı Bağlamında İncelenmesi: OYAK Örnek Olayı ${ }^{\circledR}$
}

\author{
The Analysis of Accountability and Transparency of the Firms in the Context of \\ Agency Theory: OYAK Case
}

Ümit Ercan ${ }^{\text {a }}$, Ünsal Sığrı *,b

MAKALE BILGİSI

Anahtar Kelimeler:

Vekâlet Kurami, Şeffaflık,

Hesap Verebilirlik, OYAK

\section{Tarihler:}

Geliş 08 Aralık 2017

Düzeltme geliş 26 Şubat

2018

Kabul 16 Mart 2018

\section{A R T ICLE INFO}

\section{Keywords:}

Agency Theory,

Accountability

Transparency, Turkish

Armed Forces Assistance

(and Pension) Fund.

Article history:

Received 08 December 2017

Received in revised form 26

February 2018

Accepted 16 March 2018

\section{ÖZ}

Bu çalışma, vekâlet kuramının bir örnek olay çerçevesinde incelenmesi amacılla yapılmıştır. Bu maksatla, seçilen Ordu Yardımlaşma Kurumu (OYAK) üyesi 260 katılımcıdan, geliştirilen ölçek vasıtasıyla toplanan veriler analiz edilmiş, üyelerin; vekâlet yapısı, hizmet kalitesi, şeffaflık ve hesap verebilirlik mekanizmalarl konusundaki alglları ölçülmüşür. OYAK yönetiminden 14 katılımcıla mülakat yapılmış, yönetim faaliyetleri gözlemlenmiş ve Kuruma yönelik doküman incelemesi yapılmıştır. Yönetim mekanizmaları kuram bağlamında incelenmiş, güçlü ve zayıf yanları tartışılmıştır. Kurumun şeffaflık ve hesap verebilirlik mekanizmalarıyla vekâlet sorunlarına yönelik çözümleri görülmeye çalışılmıştır.

\footnotetext{
${ }^{\text {a }}$ Bu makale birinci yazarın Savunma Bilimleri Enstitüsü’nde tamamlanan ve kabul edilen doktora tezinden türetilmiştir.

a İletişim Kurulacak Yazar, Dr., Milli Savunma Üniversitesi, Savunma Bilimleri Enstitüsü, Ankara, Türkiye. E-posta: ercanumit@yahoo.com.ORCID:0000-0003-3095-2523

*,b Prof. Dr., Başkent Üniversitesi, Spor Bilimleri Programi, Ankara, Türkiye. E-posta: usigri@baskent.edu.tr. ORCID: 0000-0002$8870-7398$
} 


\section{GİRIŞ}

Vekâlet kuramı organizasyonları sahipler adına yönetmekle görevlendirilen vekiller ile organizasyon sahipleri arasında yaşanan sorunlara odaklanan bir kuram olarak; sermayeye, organizasyona veya işyerine sahip olan asil ve onun adına işi uygulayan, yöneten vekil arasındaki ilişkidir (Jensen \& Meckling, 1976). Kuram, işi yapan taraf ile yetki veren diğer taraf arasındaki ilişkileri modellemek üzere geliştirilmiştir (Fama, 1980; Fama \& Jensen, 1983). Vekâlet Kuramı; bazı çalışmalarda güçlü ve sağlam temellere dayalı bir kuram (Jensen, 1983) bazı çalışmalarda ise insan unsurunu göz ard1 eden bir kuram (Perrow, 1986) olarak görülür.

$\mathrm{Bu}$ çalışmada, şirket yönetimlerince kullanılan şeffaflık ve hesap verebilirlik mekanizmalarının vekâlet problemlerinin çözümü konusundaki etkisinin incelenmesi amaçlanmıştır. Çalışmada, Ordu Yardımlaşma Kurumundaki (OYAK) yönetim etkinliği, vekâlet yapısı, şeffaflık ve hesap verebilirlik mekanizmaları incelenmiş, aksayan hususlar tartışılmıştır. OYAK bazı çalışmalarda "benzerlerine göre önemli başarılar gösteren ve üyelerine yönelik önemli katkılar sağlayan bir yapı" (Alper, Arıcı, Özşuca, Aydın \& Gökbayrak, 2015), bazılarında ise "devlet imkânlarını kurum menfaatlerine kullanan bir yapı” (Akça, 2010) olarak tanımlanmıştır. Kurum hukuki yapısı itibariyle tartışmalı bir durumda görülmüş (Yılmaz, 1979; Yılmaz 1991), farklı çalışmalarda kurumun hukuki yapısı tartışılmıştır (Gözler, 2009; Gözübüyük \& Tan, 2014). OYAK; anonim bir yapıya sahip, çok sayıda hissedardan oluşan, hissedar üyeleri yönetimde söz sahibi olabilen, yönetim yapıs1 itibariyle kendine has (sui generis) bir kuruluştur.

Çalışma, örnek olay çalışması olarak nitel ve nicel araştırma yöntemlerinin birlikte kullanılması ile kurgulanmıştır. Nicel çalışma ile OYAK üyelerinin kuruma yönelik algıları ölçülmeye çalışılmıştır. Kullanılan ölçekle üyelerin kendilerini temsil eden vekillerin yönetiminden memnuniyeti, vekillerin profesyonelliği ve etkinliğine yönelik algıları ölçülmeye çalışılmıştır. Çalışmanın nitel bölümünde ise Kurumun yönetim mekanizmaları, üye ilişkileri, paylaşımları ve vekil faaliyetlerinin izlenmesine yönelik alınan tedbirler incelenmeye çalışılmıştır.

\section{VEKÂLET KURAMI VE VEKÂLET SORUNLARI}

Günümüzde organizasyonlar, farklı fonksiyonları bünyelerinde barındıran yapılara dönüşmüş ve faaliyet alanlarını çeşitlendirmişlerdir. Ulaşılan büyüklük ve faaliyetlerdeki karmaşıklaşma, organizasyonların idaresinde daha karmaşık yönetim fonksiyonlarını ve profesyonel yönetim gerekliliğini ortaya çıkarmıştır. Büyüklüğü, işlev yoğunluğu ve görev karmaşıklığı artan organizasyonların sahipleri tarafından yönetimi mümkün olamamış, sahiplik ile yönetim birbirinden ayrılmıştır. Kaçınılmaz olarak gerekli donanım ve beceriye sahip bir yönetici sınıfına ihtiyaç duyulmuş, aile şirketleri yerini kurumsal yönetimlere terk etmiş ve profesyonel yöneticiler ailelerden gelen sahip yöneticilerin yerini almıştır.

Asil vekil ilişkisini inceleyen farklı araştırmacılar, kuramı farklı disiplin ve boyutlardan incelemişlerdir. Vekâlet ilişkileri farklı boyutlar ve kontrol araçlarıyla değerlendirilmiş, sözleşme yönetimi, risk yönetimi (Eisenhardt, 1989), hesap verme ve şeffaflık, sahiplik yapısı (Jensen \& Meckling, 1976) belirsizlik (Nilakart \& Rao, 1994), bilgi asimetrisi (Eisenhardt, 1989) ve hukuksal vekâlet ilişkileri (Lan \& Heracleous, 2010) gibi farklı bağlamlarla açıklanmaya çalışmıştır (Akt. Meydan \& Çetin, 2012).

Vekâlet kuramı; sermayeye, organizasyona veya işyerine sahip asil (principal) ile onun adına işi uygulayan ve yöneten vekil (agent) arasındaki ilişkidir (Jensen \& Meckling, 1976). Bu ilişkide menfaat çatışması ve kontrol problemleri olarak adlandırılan iki başat problem ortaya çıkmaktadır. Menfaat çatışması; asil ile vekilin menfaatlerinin, isteklerinin veya çalışma yöntemlerinin çakışmasıdır. Asil ve vekilin riske yönelik farklı değerlendirmeleri olduğunda, doğal olarak risk çatışması meydana gelmekte, asiller, vekillerin neyi nasıl yaptığını bilmek istemekte, bu durum vekâlet problemlerinin ikincisi olan "kontrol problemlerinin" doğmasına neden olmaktadır.

Kuram; ekonomi, maliye, muhasebe, pazarlama, siyaset bilimi, örgütsel davranış ve sosyoloji gibi alanlardan etkilenen bir kuramdır (Eisenhardt, 1989) ve bu yaklaşımlarla ele alınmıştır (Kiser, 1999; Shapiro, 2005). Vekâlet kuramına ekonomik bakışta örgütler; "bireyler arasında kurulmuş sözleşmelere dayalı ilişkiler" (Jensen \& Meckling, 1976) olarak tanımlanmıştır. Vekâlet ilişkisinde "bir taraf diğer taraf adına hareket eder" (Shapiro, 2005) ve vekâlet ilişkileri; sözleşmeler, teşvikler, izleme mekanizmaları ve vekilin maliyetlerini azaltmaya yarayacak diğer kontrol mekanizmalarından oluşur. Kuram öncelikle ekonomi yazınında ortaya konulmuş (Ross 1973; Jensen \& Meckling 1976), zamanla kurumsal yönetim alanında baskın yaklaşım olarak yerini almıştır (Zajac \& Westphal, 2004). Şirketler, vekâlet kuramına göre yeni yönetim politikalarını oluşturmaya, sözleşmelerini 
teorinin esaslarına uygun hale getirmeye, yöneticilerin kendi menfaatlerini esas alan davranışlarını bastırmaya ve vekâlet maliyetlerini düşürmeye çalışmışlardır (Shapiro, 2005). Yönetsel bakış; teşvik, kurumsal yönetim ve kontrol sistemleri başlıklı üç ana akımdan oluşmuştur. Vekâlet kuramı, politik bilimlerde "ekonomi biliminde ortaya konulduğu tarihle hemen hemen aynı zamanda" (Mitnick, 1973) ve "muhtemelen ondan bağımsız olarak" (Ross, 1973) ortaya çıkmıştır. Vekâlet kuramından çok önce hukuk yazınında vekâlet konusu yer almış (Shapiro, 2005) ve "bir kişinin hukuki sonuç doğuran tüm işlemlerde diğer bir kişi adına işlem tesis edebilme yetkisi” (DeMott, 1998) olarak tanımlanmıştır. Vekâlet kuramına sosyolojik bakış, diğer bakış açılarına göre daha derin bir bilimsel ve entelektüel temele sahiptir (Kiser, 1999). Sosyolojik bakış diğerlerinden farklı bir düşünce yapısı ile Weber (1924, 1978)'in kural koyucular ile yöneticiler arasındaki ilişkiyi incelediği çalışmasına dayanır (Kiser, 1999).

Organizasyonunun yöneticisi aynı zamanda sahibi ise vekâlet problemi yaşanmamaktadır. Ancak yöneticiyle sahip farklı kişiler olduğunda, yanlış özellikteki vekillerin işe alınması, vekillerin işten kaytarması, işi yeterli etkinlikte yönetememesi, öncelikle vekil menfaatlerinin düşünülmesi, riskten kaçınma ve asilin önemli kararlardan haberdar olamaması gibi farklı sorunlar ortaya çıkmaktadır. Vekâlet problemlerinin en önemlileri; amaç çatışması, kişisel menfaat, firsatçılık, izleme ve vekâlet maliyetleri, bilgi asimetrisi, etik zararlar, profesyonellik ve riskten kaçınma olarak siralanabilir.

Amaç çatışması, vekil menfaatleri, asil menfaatlerinden ayrıldığı anda ortaya çıkar. Vekâlet kuramı, vekillerin öncelikle kendi menfaatlerini gözetmeleri tezine dayanır ve çatışmanın en aza indirilmesine odaklanan tedbirler ve kontrol mekanizmaları geliştirmeye çalışılır. Fırsatçılık olgusunun "ortaya çıkan herhangi bir durumdan fayda sağlanması" ve "mevcut bir prensibe veya ilkeye aykırı davranılması" şeklinde iki boyutu vardır (Health, 2009).

Örgütlerde vekillerin yanlış davranışlarına karşı kullanılabilecek kurallar ve müeyyideler, kontrol sistemleri ve yaptırımlara odaklanılır. Kuram bu bağlamda, asiller adına vekillerin etkin şekilde izlendiği ve sözleşme dışına çıkılması durumunda asilleri bu konuda uyaracak mekanizmalara odaklanmıştır. Vekâlet maliyeti; vekil seçim maliyeti, hatalı seçimler ve yanlış referanslardan kaynaklanan maliyetler, ödeme maliyetleri, etik zararlar, vekil hırsızlığı, kişisel menfaatler, izleme maliyetleri, sigorta masrafları gibi birçok sebepten ortaya çıkabilir (Mitnick, 1992). Asiller suiistimal edilmekten çekindikleri için vekillerin yetkilerini kısıtlamak veya kontrol etmek için ilave süreçler, kurallar, protokoller uygularlar ve bunlar da vekâlet maliyetini artırır (Shapiro, 2005).

Profesyonellik, vekillerin temel özelliklerinden birisidir ve vekillerin görevlerindeki yetkinliğinin üst seviyeye ulaşmasıdır. Asiller, vekillerini özel bilgi ve tecrübeleri için tercih ederler. Ancak bu süreçte de hatalı tercihler ortaya çıkabilir ve asiller seçecekleri muhtemel vekillerin yeteneklerini değerlendirmekte zorlanabilirler (Sharma, 1997). Güven, vekâlet ilişkisinin temeli olmakla birlikte, bazı örgütlerde vekiller asiller tarafindan kontrol edilemeyecek kadar farklı bilgi, tecrübe, güç ve kaynaklara ulaşım asimetrisine sahiptirler. Bu durum asillerle vekiller arasında kontrol ve güven sorunlarına neden olabilir. Vekillerin asiller tarafından kontrol ve denetimini sağlayan şeffaflık mekanizmaları; vekil faaliyetlerinin asiller ve paydaşlarca izlenebilecek açıklıkta yapılmasını sağlar. Hesap verebilirlik ise yapılan faaliyetlerdeki hatalar konusunda sahiplere ve yetkili makamlara hesap verilmesidir.

Vekâlet Kuramına ilişkin genel değerlendirmeler, kuramın paradigmaları ve vekâlet problemlerine ilişkin değerlendirmeler sonrasında, çalışmanın bundan sonraki bölümünde yazından elde edilen genel ilkelerin, OYAK örnek olayı kapsamında incelemesi yapılacaktır. Yerel ekonomide önemli bir etkinliğe sahip olan OYAK yönetiminde, söz konusu problemlerin ne oranda ortaya çıktığı, kurumun asil ve vekillerinin bu sorunlara nasil çözümler getirdiği görülmeye çalışılacaktır.

\section{BİR MESLEKİ DAYANIŞMA ÖRGÜTÜ OLARAK OYAK'IN VEKÂLET KURAMI BAĞLAMINDA DEĞERLENDİRÍLMESİ}

OYAK, 01 Mart 1961 tarihli ve 205 sayllı Kanun ile kurulan tamamlayıcı bir mesleki emeklilik fonudurii. Kendi mevzuatı kapsamında üyelerine veya katılımcılarına emeklilik, ölüm ve maluliyet yardımları yaptığı gibi ayrıca isteğe bağlı olarak emekli maaşı, konut edindirme ve borç verme gibi hizmetler de sunmaktadır. OYAK Kanunu'nun 1. maddesinde kurumun genel yapısı özetlenmiş, 2 ila 14. maddeler arasında Genel Müdürlüğün yönetim faaliyetlerini denetleme ve belli oranda katılım mekanizması olarak teşkil edilen Temsilciler

\footnotetext{
ii OYAK, bir mesleki (ikincil) emeklilik fonudur. Emeklilik sistemlerinde günümüzde genel kabul gören sinıflandırma; devletin temel emeklilik sistemleri / kurumları (ülkemizdeki SGK benzeri yapılar), OYAK benzer yapılar olan ve meslek grubu mensuplarının çalışmaları esnasındaki birikimlerinden oluşan mesleki emeklilik sistemleri ile ülkemizde yakın dönemde etkin olarak faaliyet göstermeye başlayan bireysel emeklilik sistemleri șeklinde yapılmaktadır.
} 
Kurulu, Genel Kurul ve Yönetim Kurullarının yapıları ve görevleri yasal dayanağa kavuşturulmuştur. 14 ila 16. maddelerde ise asilvekil ilişkisinde vekil olarak görev yapan Genel Müdürlük yapısı ve görevleri tanımlanmıştır.

Yasanın devam eden maddelerinde kurumun sahibi ve asil unsuru olan üyelerin yapısı tanımlanmıştır. Kurumun yönetim yapısı teşkil edilirken ve kanun tasarısı hazırlanırken vekâlet yapısına ilişkin hususlar tartışılmıştıriii. Buna göre; OYAK yönetiminde OYAK üyesi TSK personeli de yer alacak, ancak bu personele ilave olarak alanlarında uzman yönetici, denetçi ve ticaret erbabı da yer alacaktır. Böylelikle, bahse konu mekanizmalarda görev yapacak askeri personelin, tamamen ticari bir yap1 olan OYAK'1n faaliyetlerinde yönetici veya denetleyici olarak görev almaya yetecek profesyonellik, bilgi birikimi ve eğitim altyapısı bulunmayacağı değerlendirmesinden hareketle yapıda uzman sivillere yer verilerek melez ve kendine özgü bir yönetim ve denetim mekanizması oluşturulmaya çalışılmıştır. Ayrıca vekâlet kuramının temel sorunlarından birisi olan profesyonellik konusundaki kurum yönetim yapısının oluşabilecek eksiklikleri başlangıç aşamasında profesyonel yönetici istihdamı ile giderilmeye çalışılmıştır.

OYAK Temsilciler Kurulu; tamamı TSK personelinden oluşan, kurumun çalışmalarını üç yılda bir değerlendiren, dilek ve temennileriyle kurum çalışmalarını yönlendiren ve tabandan gelen talepleri üst yönetime ileten yapıdır. Temsilciler Kurulu tarafindan seçilen 20 üyeye ilave olarak, Yasa gereğince tespit edilen 19 üye ile birlikte toplam 39 kişilik bir yapıya ulaşan Genel Kurul ise her y1l rutin olarak ve yine Yasa'da tanımlanan sebeplerin oluşması durumunda olağanüstü olarak toplanır. 39 kişilik yapının içinde altı bürokrat ve üç özel girişimci de kurum faaliyetlerini denetlemek üzere sisteme dâhil edilmiştir. Buna göre, Genel

\footnotetext{
iii Kuruluşundan itibaren OYAK yönetimine üyeler dısıında kendi alanınd uzman bürokrat ve is adamlarından da katk1 sağlanmıs, söz konusu sivil şahıslar yönetime yasa gereği atama veya seçim yoluyla dâhil edilmiş ve yönetimin risk alma/riske katlanma sorunu bu şekilde azaltılmaya çalıșılmıștır.

Kurum yönetiminde yer alan sivil üyelerin özellikle ekonomi, hukuk, sigorta ve emeklilik sistemleri gibi alanlardaki uzmanlardan seçilmesi yöntemiyle alınacak kararlarda bu kişilerin uzmanlıklarından (profesyonellik) faydalanılmak istenmiștir. Kanun'un hazırlanmas aşamasında da bazı milletvekilleri, özellikle Temsilciler Kurulu'nda kuvvet ve statü dengesinin sağlanması bakımından yasaya bir hüküm konulmasını teklif etmişler (Mucip Ataklı ve Osman Köksal) ve maddeye üyelerin kuvvet esasına göre seçileceğine ilişkin hüküm eklenmiştir. Burada yapılan görüsmelerde Sait Acar'ın “Temsilciler Kurulu denetim faaliyetlerini yerine getirecek ama asıl yük Genel Kurul'da olacaktır. Biz yönetim kurullarının teşkilini yeni bir sistem içinde seçilmesine dayanan
bir yapı olarak öngördük. Bu sahada tecrübesi olan hatta otorite sayılan pek çok kimselerin de fikirlerini alarak böyle bir mekanizmaya kanunda yer verdik. Burada en büyük yük Genel Kurula yüklenmistir. Bu kurula sırf askeri kuvvetlerin hâkim olmasını da arzu etmedik. Cünkü piyasayı tanımayız, ticari sahada bilgimiz azdır. Bu husustaki bilgilileri de seçebilmek için talimatnameye hükümler koymak ihtiyacındayız." seklinde açıklamalarda bulunmuștur. (205 sayılı Kanun'un Müzakere Zabıtları, Esbabı Mucibe bölümü, S.6.)
}

Kurulun \%77'si kurum üyelerinden, \%23'ü kurumla ilgisi olmayan sivillerden oluşmaktadır.

Kurum yönetim faaliyetleri ve mali yapısının denetlenmesi konusunda yetkili makam olan Denetleme Kurulunda bir asker üyeye karş1lık Sayıştay'dan bir ve Türkiye Bankalar Birliği'nden bir olmak üzere üç üye yer alır. Denetleme Kurulunun \%33'ü TSK personelinden, \%66's1 ise sivil şahıslardan oluşmaktadır. OYAK Yönetim Kurulu ise 8 üyeden oluşmaktadır. Genel Müdür dışındaki üç üye Genel Kurul tarafından seçilen OYAK üyesi personeldir. Diğer dört üye ise yine Kanun'la oluşturulan seçim komitesi tarafindan belirlenen üyelerdir. Yönetim Kurulunun \%37'lik kısmını kurum üyeleri, Genel Müdürün de dâhil olduğu sivil şahıslar ise \%63'lük bir bölümü oluşturmaktadır.

OYAK yönetim ve denetim kademelerinde asker üyelere ilave olarak alanında uzman sivil şahıslardan (bürokrat, denetçi, iş adamı vb.) üye seçimi vasıtasıyla daha profesyonel bir yönetim yapısına sahip olunmasının amaçlandı̆̆ değerlendirilmektedir. Kurum üyesi temsilcilerle vekillerin asiller tarafindan denetimine olanak sağlanmaya çalışılırken, asillerin kurum yönetimi ve yatırım politikası belirlemek konusundaki eksikliklerinin giderilmeye çalışıldı̆̆ görülmektedir. Ayrıca oluşturulan hibrit yapı ile amaç çatışması, kişisel menfaatlere önem verilmesi, izleme ve vekâlet maliyetleri ile bilgi asimetrisinin önlenmesinin amaçlandığı değerlendirilmiştir.

OYAK'ın şeffaflık ve hesap verebilirlik mekanizmalarını geliştirmek maksadıyla; üye iletişim sistemini ve kurum denetim mekanizmalarını kullanmaya çalışmakta ve faaliyetlerini kamuoyu ile paylaşmaya gayret etmektedir. Türk Ticaret Kanunu ve OYAK Kanunu hükümlerine göre Kurum, mali defter ve tablolarını tutmak mecburiyetindedir. Ayrica OYAK Kanunu'nun 11 ve 38 . maddeleri gereğince 5 yılda bir mali durumu hakkında aktüeryal denetim yaptırmaktadır. Ayrıca, şeffaflık politikaları kapsaminda Moody's ve Standarts \& Poor's tarafindan faaliyetlerini ve kurumsal yapısını derecelendirmeye tabi tutturmaktadır. Yapılan derecelendirmeler, yerel ve uluslararası piyasalara ilan edilmekte ve kurum resmi internet sayfasında da duyurulmaktadiriv ${ }^{\text {iv }}$

\footnotetext{
iv Moody's tarafindan OYAK 2017 yılı Mart ayından beri "Baa3 / Negatif Görünüm” olarak değerlendirilmektedir. Aynı dönem için Türkiye'nin ülke değerlendirme derecesi "Ba1 / Negatif Görünüm" olarak ilan edilmiştir. Kurum ülke puanına göre daha yüksek olarak değerlendirilmiş ve gerekçe olarak Kurum'un güçlü mali yapısı gerekçe gösterilmiştir. Standard \& Poor's (S\&P) 25 Temmuz 2016 tarihinden itibaren OYAK'ın kredi notunu Türkiye ülke kredi notunun indirilmesine paralel olarak uzun dönem kredi notunu 'BB+' kısa dönem kredi notunu ise ' $\mathrm{B}$ ' olarak açıklamıștır.
} 
Tablo 1: Görüşme Örneklemine Ait Betimleyici İstatistikler

\begin{tabular}{lccl}
\hline Yönetim Yapısı & Üye & Mülakat & Katılımcı Özellikleri \\
\hline Temsilciler Kurulu & 75 & 5 & 1 Memur, 1 Uzm.Erb., 2 Astsb., 2 Subay \\
Genel Kurul & 39 & 4 & 1 Uzm.Erb. 1 Astsb. 1 Subay, 1 Sivil \\
Yönetim Kurulu & 8 & 3 & 1 Astsb, 2 General \\
Denetleme Kurulu & 3 & 2 & 1 General, 1 Sivil \\
\hline
\end{tabular}

Çalıșmanın bundan sonraki bölümünde; Kurum, yönetim ve denetim faaliyetlerinde vekâlet ilişkisinin ne şekilde oluşturulduğu, üyelerin oluşturulan yapıya ve hizmetlere yönelik algıları, yönetim/denetim görevlerinde yer alanların aynı konulara yönelik değerlendirmeleri ölçülmeye çalışılacaktır. Ayrıca gözlem, mülakat ve doküman analizi ile elde edilen veriler tartışılacaktır.

\section{YÖNTEM}

$\mathrm{Bu}$ çalışma, nitel ve nicel yöntemlerin birlikte kullanıldığı bir "karma yöntem araştırması"dır. Çalışmanın nitel araştırma deseni "örnek olay" çalışmasıdır. Kuramına ilişkin yazında tartışılan boyutlar, OYAK üzerinden incelenmeye çalışılmış ve bu vaka bağlamında vekâlet kuramının test edilmesi amaçlanmıştır. Konu ve örneklemin anlık durumunun ortaya konulması maksadıyla nicel araştırma yöntemi ile daha uzun süreli bir bakış açısı sağlayan, gözlem, mülakat ve doküman incelemesini içeren nitel araştırma yöntemleri birlikte kullanılmıştır. OYAK yönetim kademelerinde görev yapan yöneticilerle "görüşme" yapılmış, kamuoyuna açıklanan performans ve değerlendirme kriterleri "doküman incelemesi" ile analiz edilmiş, kuruluşundan günümüze faaliyetleri "arşiv araştırması" ile incelenmiş ve "doğrudan gözlem" yapılarak kurum faaliyetleri gözlenmiştir. Kurum üyelerine "OYAK Yönetim ve Hizmet Faaliyetleri Ölçeği” uygulanarak yönetim yapısı, şeffaflık ve hesap verebilirlik mekanizmalarının etkinliği ve alınan hizmetin kalitesi ölçülmeye çalışılmıştır. Çalışmanın nitel bölümündeki örneklem, amaçlı örneklem yöntemiyle seçilen OYAK yönetim ve denetim görevlerinde yer alan yöneticilerden oluşmuştur. Nicel bölüm için tabakalı örneklem metodu tercih edilmiştir.

\section{1. Örneklem}

Çalışmanın vekil evrenini ve nicel araştırma bölümünü oluşturan OYAK zorunlu ve gönüllü üye sayıs1 305728 kişidir. Çalışmada bu evreni temsil etmek üzere tabakalı örneklem yöntemiyle ulaşılan toplam 300 üyeye anket uygulanması planlanmıştır. Gönderilen anketlerden 266 adedi geri dönmüş ve 260 adedi analiz için uygun bulunmuştur. Katılımciların \%90'1 erkek (n=234), \%10'u (n=26) kadındır. Katılımcıların, \%13,1'i lise $(n=34)$,
$\% 12,7$ 'si ön lisans $(\mathrm{n}=12,7), \quad \% 50,4$ 'ü lisans $(n=131)$ ve $\% 23,8$ 'i lisansüstü $(n=62)$ eğitimine sahiptir. Üyelik süresine göre; \%8,8'i $1-5$ y1 $(n=23), \% 15,8$ 'i 5-10 y1l (n=41) ve \%51,2'si 10-20 y1l $(n=133)$ ve \%24,2'si $(n=63) 20$ yildan fazla üyelik süresine sahiptir. Araştırmaya katılanlardan \%93'ü halen çalışmakta ( $\mathrm{n}=242), \% 7$ 'si ise emekli $(n=18)$ ancak OYAK üyeliği devam eden kişilerdir. Katılımcıların \%33'ü subay ( $\mathrm{n}=86), \% 41$ 'i astsubay $(n=107), \% 15,5^{\prime}$ i uzman erbaş $(n=40)$ ve $\% 10,5^{\prime} i$ $(\mathrm{n}=27)$, memurdur. Zorunlu üyeler örneklemin \%74'ünü $(n=193)$, gönüllü üyeler \%26'sını $(n=67)$ oluşturmaktadır.

Araştırmanın görüşme bölümünün örneklemi, OYAK yönetim ve denetim organlarında görev yapan toplam 125 üyeden seçilen 14 üye oluşturmaktadır. Çalışmada Temsilciler Kurulu'ndan 5, Genel Kurul'dan 4, Yönetim Kurulu'ndan 3 ve Denetim Kurulu'ndan 2 olmak üzere toplam 14 üye ile görüşme yapılmıştır.

Örneklemin seçiminde her kademeden katılımcı seçimine özen gösterilmiştir. Katılımcılara görüşme formunda yer alan açı/kapalı uçlu sorular yöneltilerek vekâlet kuramının OYAK uygulamaları, şeffaflık ve hesap verebilirlik mekanizmaları ve kurum üye ilişkilerine yönelik görüşleri alınmaya çalışılmıștır. Çalıșmada, OYAK vekâlet mekanizmalarının örnekleri olan Genel Kurul ve Temsilciler Kurulu faaliyetleri gözlemlenmiştir. Gözlem faaliyetlerinde katılımcı gözlem metodu uygulanmış, üyelere araştırmacının gözlemci kimliği hakkında bilgi verilmiştir. Gözlem sürecinde üyelerin faaliyetleri kendi doğal ortamlarında incelenmiş, gerek görülen durumlarda katılımcıların görüşleri alınmaya çalışılmıştır. Çalışmada "Doküman İncelemesi" kapsamında kurumun 1961 yılı sonrasında kamuoyu ile paylaşılan verileri incelenmeye çalışılmıştır. Buna göre; yasal çerçeve, vekâlet yapısı,, şeffaflık ve hesap verebilirlik mekanizmaları ile kurum üye ilişkileri incelenmiştir.

\subsection{Nicel Veri Toplama Araçları, Güvenirlik ve Geçerlik}

OYAK üyelerinin yönetim yapısı, şeffaflık ve hesap verebilirlik mekanizmalarının etkinliği ve alınan hizmetin kalitesinin ölçüldüğü ölçek, bu çalışma için geliştirilmiştir. Yedili likert tipinde "OYAK'ın 
yönetim organlarında TSK personelinin yeterince temsil edildiğine inanmiyorum", "OYAK yönetiminin profesyonel bir yapıya sahip olduğunu düşünüyorum", "OYAK yönetim faaliyetleri ve yatırımları ile yardımları konusunda üyelerine ve kamuoyuna yeterince bilgi vermemektedir" gibi ifadeler içeren 16 maddeden oluşmakta ve dört faktörlü yapı içermektedir. Ölçek maddeleri vekâlet kuramı yazından geliştirilmiş ve OYAK'ta vekâlet yapısının ne şekilde oluştuğu, vekâlet ilişkisinin kuramda yer alan vekâlet sorunlarını taşıyıp taşımadığı, kurum yönetim yapısının şeffaf ve hesap verebilir bir yapıda olup olmadığına yönelik üye algıları ölçülmeye çalışılmıştır. Ayrıca dördüncü bir faktör olarak üyelerin OYAK faaliyetlerinden ve aldıkları hizmetlerden memnun olup olmadıkları ölçülmeye çalışılmıştır.

Ölçek, görünüş ve içerik geçerliği kapsamında alan uzmanı üç akademisyene gönderilerek kendilerinden ölçekle ilgili geri bildirimler alınmıştır. Alınan geri bildirimler doğrultusunda ölçeğin üye algılarını daha ayrıntılı ölçebilmesi ve daha geniş bir aralıkta yayılımın sağlanması amaciyla 5'li likert yerine 7'li likert olarak düzenlenmesi sağlanmıştır. Katılımcıların yanıtlama ciddiyetinin sağlanması maksadıyla bir kısım sorular ters olarak kodlanmıştır. Ayrıca katılımcılar tarafindan anlaşılması zor olduğu değerlendirilen bazı maddeler daha basit hale getirilmiştir. Katılımcıların eğitim seviyeleri de dikkate alınarak bazı maddeler daha anlaşılır hâle getirilmiş ve maddelerin katılımc dikkatini yüksek seviyede tutulması maksadıyla az sayıda olmasına özen gösterilmiştir. Böylelikle 16 madde haline getirilen ölçek ile her bir boyuta ilişkin algıların dörder madde ile ölçülmesi hedeflenmiştir.

Kullanılan Ölçeğin Cronbach alfa değerinin 0,86 olduğu görülmüş, ölçeğin yapısal geçerliğini tespit etmek amaciyla temel bileşenler analizi ve "varimaks" eksen döndürmesi tekniği kullanılarak "keşfedici faktör analizi" (KFA) uygulanmıştır. KFA neticesinde Kaiser-Meyer-Olkin (KMO) örneklem yeterlik değerinin 0,89 olduğu ve örneklem büyüklügünün faktör analizi için yeterli olduğu tespit edilmiştir. Bartlett küresellik testinin anlamlı olmasi $\left.\left[\chi^{2}(120)=1781,501, p<0,001\right)\right]$ maddeler arasındaki korelasyon ilişkilerinin faktör analizi için uygun olduğunu göstermektedir. KFA'da özdeğerlerin 1'den büyük olması ile faktörlerin oluşması sağlanmıştır. KFA neticesinde dört faktörlü bir sonuç elde edilmiştir. Yamaç serpinti grafiği ve faktörlerin açıkladıkları

Tablo 2: Ölçeğin KFA Sonuçları

\begin{tabular}{|c|c|c|c|c|}
\hline Madde & Memnuniyet & $\begin{array}{c}\text { Hesap } \\
\text { Verebilirlik }\end{array}$ & Şeffaflık & $\begin{array}{l}\text { Vekâlet } \\
\text { Etkinliği }\end{array}$ \\
\hline Soru 6 & ,781 & & & \\
\hline Soru 8 & 634 & & & \\
\hline Soru 9 & ,697 & & & \\
\hline Soru 12 & ,788 & & & \\
\hline Soru 15 &, 731 & & & \\
\hline Soru 3 & & ,503 & & \\
\hline Soru 10 & & 649 & & \\
\hline Soru 11 & &, 814 & & \\
\hline Soru 14 & & ,748 & & \\
\hline Soru 5 & & &, 521 & \\
\hline Soru 7 & & &, 583 & \\
\hline Soru 13 & & &, 780 & \\
\hline Soru 16 & & & ,598 & \\
\hline Soru 1 & & & &, 838 \\
\hline Soru 2 & & & & ,808 \\
\hline $\begin{array}{l}\text { Özdeğerler } \\
\text { (Eigenvalues) }\end{array}$ & 6,285 & 1,748 & 1,119 & 1,047 \\
\hline $\begin{array}{l}\text { Açılklanan Varyans } \\
\%\end{array}$ & 21,464 & 16,304 & 14,726 & 11,691 \\
\hline $\begin{array}{l}\text { Toplam Açılanan } \\
\text { Varyans } \%\end{array}$ & \multicolumn{4}{|c|}{64,186} \\
\hline
\end{tabular}


varyanslar da dört faktörlü yapıyı desteklemiştir. Bu kapsamda beklenenden farklı faktörler altında yer alan maddeler ilgili olduğu değerlendirilen faktör altında değerlendirilmiş, çapraz yüklenme eğilimi gösteren bir maddenin ölçekten çıkarılmasına karar verilmiştir.

Yeniden yapılan KFA sonucunda 15 maddelik ölçeğin dört faktörlü bir yapıda olduğu, faktörlerin toplam varyansın \%64,186'sını açıkladığı ve maddelerin faktör yüklerinin 0,5 'in üzerinde olduğu tespit edilmiştir. 15 maddelik ölçek maddeleri ve maddelerin faktörlerdeki yüklerine ilişkin KFA sonuçları Tablo-2'de gösterilmiştir.

Tablo-2'de görüldüğü üzere döndürme işleminden sonra birinci faktör $\% 21,64$, ikinci faktör $\% 16,30$, üçüncü faktör \%14,73 ve dördüncü faktör \%11,69 oranında varyansı açıklamaktadır. Faktör altında yüklenen maddeler ve kuramsal beklentilerden yola çıkılarak bu faktörler; "Kurum Hizmetleri ve Üyeliğinden Memnuniyet”, “OYAK'ın Hesap Verebilirliği", "OYAK'ın Şeffaflığı" ve "Kurum Vekâlet Yapısı" şeklinde adlandırılmıştır. Bu sonuçlar, 15 maddeden oluşan ölçeğin dört faktörlü yapısının geçerliğine işaret etmektedir.

Ölçek değişkenlerinin oluşturduğu yapı altında yatan ilişkileri test etmek ve kuramsal olarak geliştirilen hipotezlerin doğrulanması amacıyla AMOS 6.0 programı kullanılarak "doğrulayıc1 faktör analizi" (DFA) yapılmıştır. DFA sonuçlarına göre ve boyutları ölçen maddelerde yapılan değişiklikler sonrasında boyutlar ve boyutları ölçen maddeler Şekil-1'de açıklandığı gibi gerçekleşmiştir.

DFA sonucunda elde edilen uyum indeksleri test edilen modelin toplanan verilerle desteklenip desteklenmediğini açıklamaktadırlar. Dört alt boyut

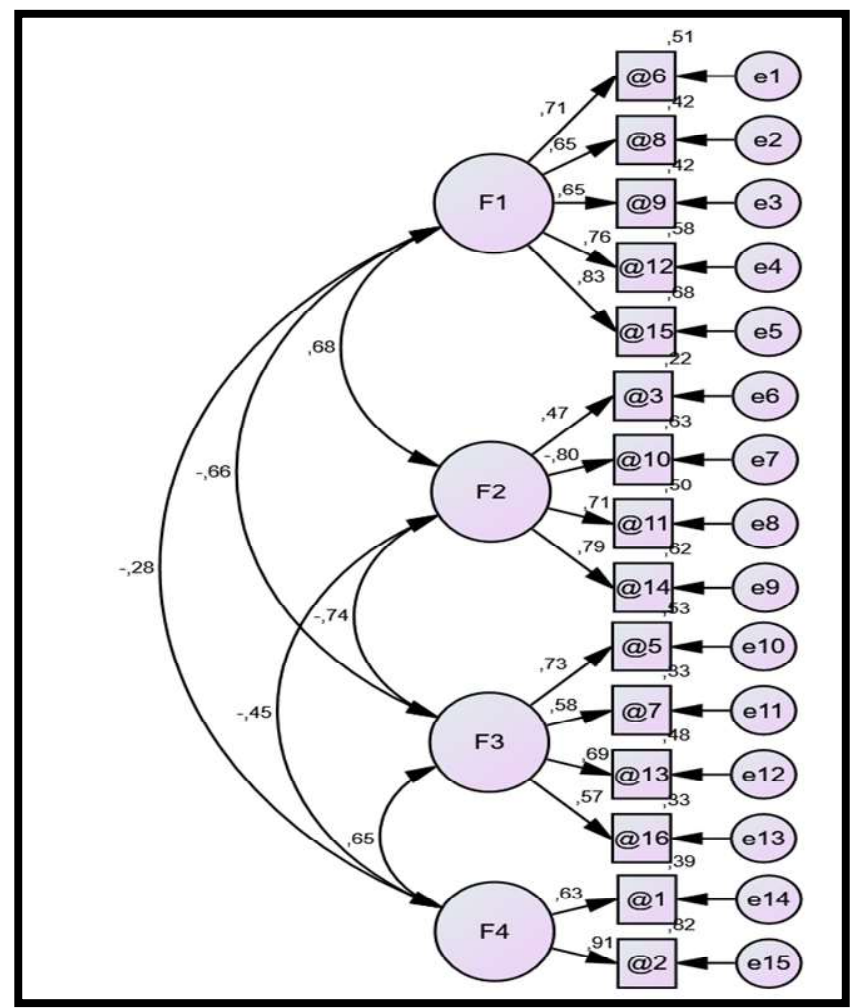

Şekil 1: Ölçek Boyutları ve Birinci Düzey DFA Sonuçları

Tablo 3: OYAK Yönetim ve Hizmet Faaliyetleri Ölçeği DFA Sonuçları

\begin{tabular}{ccccc}
\hline Model & $\Delta \boldsymbol{\gamma}^{2}$ & $\Delta \boldsymbol{\gamma}^{2} / \mathbf{s d}$ & RMSEA & CFI \\
\hline Dört Boyutlu Model & 220,403 & 2,624 & 0,079 & 0,911 \\
\hline
\end{tabular}

RMSEA: Root Mean Square Error of Approximation; CFI: Comparative Fit Index; 
ve toplam 15 maddeden oluşan OYAK Yönetim ve Hizmet Faaliyetleri Ölçeği, birinci düzey çok faktörlü model olarak gerçekleşmiştir. Yedili likert ölçeğinde, 260 katılımcıdan toplanan değerler normal dağılım göstermiştir. Birinci düzey DFA neticesinde elde edilen uyum iyiliği değerleri $\left[\chi^{2}(\mathrm{~N}=260)=220,403 ; \quad \mathrm{p}<0,01 ; \quad \chi^{2} / \mathrm{sd}=2,624 ;\right.$ $\mathrm{RMSEA}=, 079 ; \mathrm{CFI}=, 911]$ önerilen dört faktörlü modelin veri ile uyumlu ve kabul edilebilir olduğunu göstermektedir. Tablo-3'de sunulan sonuçlar, araştırmadan elde edilen verilerin, ölçek ile öngörülen kuramsal yap1 (dört faktörlü model) ile uyuştuğunu göstermiştir.

\subsection{Nitel Veri Toplama Araçları, Güvenirlik ve Geçerlik}

Araştırmanın nitel bölümünde mülakat, gözlem ve doküman incelemesi yöntemleri kullanılmıştır. Böylelikle birden farklı yöntem kullanılarak elde edilen verilerin birbirleriyle olan ilişkisi ortaya konulmaya çalışılmıştır. Ayrıca yöntem çeşitlendirmesi ile analiz sonuçlarının geçerliğinin ve güvenirliğinin artırılması amaçlanmış, nitel veriler ile nicel veriler arasındaki ilişki de açıklanmaya çalışılmıştır. Diğer yandan, nitel veri elde etme ve verilerin analizi süreçleri mümkün olan ayrıntıda açıklanmaya çalışılmıştır. Elde edilen tüm veriler, elde edilme süreçleriyle birlikte ayrıntılı olarak anlatılarak geçerliği artırılmaya çalışılmıştır. Nitel araştırmalarda birden fazla yöntemin kullanılmasıyla sağlanan "yöntem çeşitlemesi” kapsamında öncelikle araştırma soruları geliştirilmiş, çalışılacak durum saptanmış, araştırmaya katılacak bireyler tespit edilmiş ve veriler aşağıda belirtilen veri toplama teknikleri kullanılarak toplanmış ve analiz edilmiştir.

\section{BULGULAR}

Nicel bölüme ilişkin istatistiksel bulgular genel olarak iki kısımda incelenecektir. Birinci kısımda, nicel bölümde kullanılan ölçeğin faktörlerinin betimleyici istatistikleri, ikinci kısımda demografik değişkenlerin ölçeğin alt boyutlarını ne şekilde

Tablo 4: Değişkenlere İlişkin Betimleyici İstatistikler

\begin{tabular}{lccccc}
\hline \multicolumn{1}{c}{ Değişken } & Toplam & Ort. & Min. & Maks. & s.s. \\
\hline Memnuniyet & 260 & 5,37 & 1,20 & 7,00 & 1,17 \\
Hesap Verebilirlik & 260 & 4,39 & 2,00 & 6,50 &, 80 \\
Şeffaflık & 260 & 4,05 & 1,00 & 7,00 & 1,45 \\
Vekâlet Etkinliği & 260 & 4,03 & 1,00 & 7,00 & 1,73 \\
\hline
\end{tabular}

Tablo 5: Görev Süresine Göre ANOVA Sonuçları

\begin{tabular}{|c|c|c|c|c|c|c|c|}
\hline Boyut & & $\begin{array}{l}\text { Kareler } \\
\text { Toplamı }\end{array}$ & sd & $\begin{array}{c}\text { Kareler } \\
\text { ortalaması }\end{array}$ & $\mathbf{F}$ & $\mathbf{p}$ & Anlamlı Fark \\
\hline \multirow{3}{*}{ Memnuniyet } & Gruplararas1 & 13,119 & 3 & 4,373 & 3,252 &, 022 & $1-2$ \\
\hline & \multirow[t]{2}{*}{ Gruplariçi } & 344,207 & 256 & 1,345 & & & \\
\hline & & 357,326 & 259 & & & & \\
\hline \multirow{5}{*}{$\begin{array}{l}\text { Hesap } \\
\text { verebilirlik }\end{array}$} & Toplam & & & & & & \\
\hline & Gruplararas 1 & 1,926 & 3 & ,642 & ,999 & ,394 & - \\
\hline & Gruplariçi & 164,611 & 256 & 643 & & & \\
\hline & & 166,537 & 259 & & & & \\
\hline & Toplam & & & & & & \\
\hline \multirow{4}{*}{ Şeffaflık } & Gruplararas1 & 13,513 & 3 & 4,504 & 2,148 & ,095 & - \\
\hline & Gruplariçi & 536,905 & 256 & 2,097 & & & \\
\hline & & 550,418 & 259 & & & & \\
\hline & Toplam & & & & & & \\
\hline \multirow{4}{*}{ Vekâlet } & Gruplararas1 & 14,465 & 3 & 4,822 & 1,621 & , 185 & - \\
\hline & Gruplariçi & 761,568 & 256 & 2,975 & & & \\
\hline & & 776,034 & 259 & & & & \\
\hline & Toplam & & & & & & \\
\hline
\end{tabular}


farklılaştırdığı tartışılacaktır. Araştırmanın nitel bulguları ise; katılımcılarla yapılan görüşme verilerinin incelenmesi, gözlem sürecinde elde edilen verilerin incelenmesi ve OYAK faaliyetlerine ilişkin dokümanların analiz edilmesi olmak üzere üç kısımda tartışılacaktır.

\subsection{Nicel Analiz Bulguları}

Araştırmada kullanılan ankette yer alan değişkenlerin minimum, maksimum, ortalama değerleri ile standart sapmaları Tablo-4'de verilmiştir.

Buna göre; katılımcıların OYAK'a yönelik değerlendirmelerinin genel anlamda olumlu olduğu görülmektedir. Üyelerin OYAK faaliyetlerinden memnuniyeti yüksek seviyede (Ort. $=5,37$; ss. $=1,17$ ) gerçekleşmiştir. Katılımcılar, OYAK'ın hesap verebilir bir yapıda olduğu ve yaptığ 1 faaliyetleri konusunda üyelere ve kamuoyuna hesap verdiğini değerlendirmişlerdir (Ort. $=4,39$; ss. $=0,8)$. Üyelere göre OYAK'ın şeffaflık yapısı da ortalamanın üzerindedir (Ort. $=4,05$; ss. $=1,45)$. Son değişken olan OYAK yönetim yapısının vekâlet etkinliği ise düşük değerlerde ve ortalama değerin biraz üzerindedir (Ort.=4,03; ss.=1,73). Son iki değişken olan şeffaflık ve etkin vekâlet yapısı konusunda verdikleri cevapların standart sapmalarındaki yükseklik, bir kısım katılımcının OYAK faaliyetlerindeki şeffaflık ve yönetimde etkin bir vekâlet yapısının teşkil edildiği konusunda olumsuz değerlendirmeleri olduğunu göstermektedir.

\subsubsection{Demografik Değişkenlerin Etkisi}

Demografik faktörlerin, nicel araştırma değişkenlerine etkisinin görülebilmesi maksadıyla tek yönlü varyans analizi (ANOVA) yapılmıştır. Varyansların homojen olup olmadığı Levene $\mathrm{F}$ testiyle kontrol edilmiş ve homojen olan $(p>0,05)$ verilerle analize devam edilmiş ve tek faktörlü varyans analiziyle anlamlılığı uygun olan $(\mathrm{p}<0,05)$ gruplar arasındaki farklılıklar incelenmiştir. OYAK üyelerinin üyelik sürelerine göre OYAK yönetim, şeffaflık, hesap verebilirlik ve memnuniyet algılarının farklılaşıp farklılaşmadığını ortaya koymak maksadıyla katılımcıların görev süreleri; (1) 0-5 y1l, (2) 5-10 y1l, (3) 10-20 yıl ve (4) $20 \mathrm{y} 1 \mathrm{l}$ ve üzeri olacak şekilde dört kategoriye ayrılmıştır. Gruplar arasındaki farklilıklar Tablo-5'de görülmektedir.

Buna göre; görev süresi değişkeni, memnuniyet boyutunda, istatistiksel bakımdan bir farklılık oluştururken $[\mathrm{F}(3,256)=3,252 ; \mathrm{p}<0,05]$ bu faktör dışında kalan boyutlar üzerinde anlamlı olarak bir fark yaratmamaktadır. Bu sonuçlara göre, diğer

Tablo 6: Üyelik Memnuniyetinin Görev Süresine Göre Karşılaştırması

\begin{tabular}{rlcccc}
\hline Değişken & \multicolumn{1}{c}{ Grup } & n & Ort. & S & F \\
\hline \multirow{3}{*}{ Memnuniyet } & $0-5$ y1l & 23 & 4,9652 & 1,11787 & \multirow{2}{*}{$5,094^{*}$} \\
& 5-10 y1l & 41 & 5,5220 & 1,01674 & \\
& 10-20 y1l & 133 & 5,2436 & 1,25971 & \\
& 20 y1l ve üzeri & 63 & 5,6857 & 1,03095 & \\
\hline
\end{tabular}

$* \mathrm{p}<0,05 \quad * * \mathrm{p}<0,01$

Tablo 7: Statülere Göre ANOVA Sonuçları

\begin{tabular}{|c|c|c|c|c|c|c|c|}
\hline Boyut & & $\begin{array}{l}\text { Kareler } \\
\text { Toplamı }\end{array}$ & Sd & $\begin{array}{c}\text { Kareler } \\
\text { ortalamas } \\
1\end{array}$ & $\mathbf{F}$ & $\mathbf{p}$ & $\begin{array}{c}\text { Anlamlı } \\
\text { Fark }\end{array}$ \\
\hline \multirow{3}{*}{ Memnuniyet } & Gruplararası & 2,899 & 3 & 966 & \multirow[t]{3}{*}{, 698} & \multirow[t]{3}{*}{.554} & \multirow[t]{3}{*}{-} \\
\hline & Gruplariçi & 354,427 & 256 & 1,384 & & & \\
\hline & Toplam & 357,326 & 259 & & & & \\
\hline \multirow{3}{*}{$\begin{array}{l}\text { Hesap } \\
\text { verebilirlik }\end{array}$} & Gruplararası & 2,518 & 3 & 839 & \multirow[t]{3}{*}{1,310} & \multirow[t]{3}{*}{,272 } & \multirow[t]{3}{*}{ - } \\
\hline & Gruplariçi & 164,019 & 256 & ,641 & & & \\
\hline & Toplam & 166,537 & 259 & & & & \\
\hline \multirow{3}{*}{ Şeffaflık } & Gruplararas 1 & 24,276 & 3 & 8,092 & \multirow{3}{*}{3,937} & \multirow[t]{3}{*}{,009 } & $2-3$ \\
\hline & Gruplariçi & 526,142 & 256 & 2,055 & & & $3-4$ \\
\hline & Toplam & 550,418 & 259 & & & & \multirow{4}{*}{ - } \\
\hline \multirow{3}{*}{ Vekâlet } & Gruplararası & 5,520 & 3 & 1,840 & \multirow[t]{3}{*}{,611 } & \multirow[t]{3}{*}{,608 } & \\
\hline & Gruplariçi & 770,513 & 256 & 3,010 & & & \\
\hline & Toplam & 776,034 & 259 & & & & \\
\hline
\end{tabular}


Tablo 8: Şeffaflığın Statülere Göre Karşılaştırması

\begin{tabular}{|c|c|c|c|c|c|}
\hline Değisşken & Grup & $\mathbf{N}$ & Ortalama & $\mathbf{S}$ & $\mathbf{F}$ \\
\hline \multirow{4}{*}{ Şeffaflık } & Subay & 86 & 3,9186 & 1,47800 & \multirow{4}{*}{$3,937 * *$} \\
\hline & Astsubay & 107 & 4,4065 & 1,43841 & \\
\hline & Uzman Erbaş & 40 & 3,7250 & 1,11488 & \\
\hline & Memur & 27 & 3,6204 & 1,67184 & \\
\hline
\end{tabular}

özelliklere göre istatistik açıdan anlamlı bir fark oluşturan OYAK üyeliğinden memnuniyet boyutunun farklı grupların ortalamalarına ait karşılaştırmalar Tablo-6'da sunulmuştur.

Tablo-6'daki değerlerden de anlaşılacağı üzere, OYAK üyelerinin OYAK hizmetlerinden ve OYAK'a üye olmaktan memnuniyetlerinin genel anlamda yüksek seviyede olduğu, ancak OYAK'a yeni üye olan üyelerin memnuniyet seviyesinin daha eski üyelere göre daha düşük seviyede olduğu söylenebilir.

\subsection{2. Üyelerin Statülerine Göre Algıları}

Üyelerin statülerine göre OYAK yönetim, şeffaflık, hesap verebilirlik ve memnuniyetlerine göre algılarının farklılaşıp farklılaşmadığını ortaya koymak maksadıyla katılımcıların statüleri; (1) subay, (2) astsubay, (3) uzman erbaş ve (4) memur olacak șekilde dört kategoriye ayrılmıștır. Gruplar arasındaki farklılıklar Tablo-7'de görülmektedir. Buna göre, farklı statüdeki üyelerin OYAK'a ilişkin "şeffaflı" değerlendirmelerinde istatistiksel bakımdan bir farklılık oluștururken $[\mathrm{F}(3,256)=$ 3,937; $<<0,01]$ bu faktör dışında kalan boyutlar üzerinde anlamlı olarak bir fark yaratmamaktadır.

Diğer özelliklere göre istatistiksel açıdan anlamlı bir fark oluşturan şeffaflık boyutunun farklı grupların ortalamalarına ait karşılaştırmalar Tablo8 'de sunulmuştur.

OYAK üyelerinin, genel anlamda OYAK yönetim faaliyetlerinin şeffaf bir yapıda yürütüldügünü̈ değerlendirdikleri görülmektedir. Ancak OYAK faaliyetlerinin şeffaflığı konusunda en yüksek yargiya astsubay statüsündeki personel sahiptir. Astsubayları, subaylar ve uzman erbaşlar takip ederken şeffaflığın en az olduğunu düşünen statü memurlardır. Diğer bir bakış açısıyla değerlendirildiğinde zorunlu üye olan subay ve astsubaylarda kurum faaliyetlerinin şeffaf olduğuna ilişkin inanç daha yüksek seviyede yer alırken gönüllü üyeler olan uzman erbaş ve memurlarda bu inanç daha düşük seviyelerde kalmaktadır.

\subsection{Nitel Analiz Bulguları}

\subsubsection{Görüșme Bulguları}

OYAK yönetim ve denetim makamlarının evrenini temsil edecek şekilde belirlenen 14 yönetici ve denetçi üye ile görüşme formu ile yarı yapılandırılmış mülakatlarla, kurumdaki sorunlar veya çözümlerine yönelik değerlendirmeleri görülmeye çalışılmıștır. Görüşmelerde katılımcılara yöneltilen sorulara ve alınan cevaplar aşağıdaki Tablo-9‘da özet olarak yer almaktadır.

Katılımcılara OYAK yönetim yapısına ilişkin açık uçlu sorular sorulmakla birlikte raporlama gerekliliği bakımından cevaplar Tablo-9'da görüldüğü şekilde özetlenmeye çalışıllmıştır. Cevaplar genel olarak değerlendirildiğinde, Yönetim/Denetim Kurullarında görev yapan üyelerin sorulara genellikle olumlu cevap verdikleri görülmüştür. Yönetim/Denetim Kurulu üyeleri; kurumun şeffaf bir yapıda olduğu, üyelerine hesap verir bir yönetim anlayışına sahip olduğu, kurumun etkin bir şekilde yönetildiği ve üyelerle iletişimin yeterince sağlandığı yönünde değerlendirme yaptıkları görülmüştür. Genel Kurul/Temsilciler Kurulu'nda görev yapan üyelerin verdikleri cevapların ise Yönetim/Denetim Kurulu üyelerinden daha az kesinlik ifade ettiği görülmüştür. Sekiz ana alanda sorulan sorulara genellikle olumlu ve yüksek oranda cevap verilirken özellikle "OYAK yönetim/denetim organlarına seçim süreçlerinin etkinliği” ve "bu görevlerdeki kişiler görevleri yeterli etkinlikte yerine getirebilmeleri" sorularına olumsuz cevaplar verilmiştir.

Genel oranlara bakıldığında "OYAK, üyeleri ile gerekli iletişimi sağlamaktadır" ve "OYAK mali kayıtlart yeterince denetleniyor" sorularına verilen olumlu cevaplar en yüksek orana (\%86) ulaşırken, "OYAK yönetim/denetim organlarına seçim süreçleri yeterince etkindir" ve "Bu görevlerdeki kişiler görevleri yeterli etkinlikte yerine getirebiliyorlar" sorularına verilen cevaplar daha düşük oranda (\%64) gerçekleşmiştir. Görüşme sürecinde elde edilen verilerin oluşturulan kodlar ve temalar ile analiz edilmesine geçilmeden önce, katılımcıların sorulara vermiş oldukları cevapların betimsel analizi yapılacaktır. $\mathrm{Bu}$ maksatla katılımcıların adları yerine onları tanımlayacak kodlar kullanılmıștır (Genel Kurul G1， G2,.., Temsilciler Kurulu T1, T2.., Yönetim Kurulu Y1, 
Tablo 9: Görüşme Sonuçları Özet Tablosu

\begin{tabular}{|c|c|c|c|c|c|c|c|c|c|c|c|c|c|c|c|c|}
\hline \multirow{3}{*}{ Katılımcıların Görüşleri } & \multicolumn{14}{|c|}{ Katılımcılar } & \multirow{3}{*}{$\frac{\Xi}{\tilde{z}}$} & \multirow{3}{*}{$\%$} \\
\hline & \multicolumn{5}{|c|}{$\begin{array}{c}\text { Temsilciler } \\
\text { Kurulu }\end{array}$} & \multicolumn{5}{|c|}{ Genel Kurul } & \multicolumn{2}{|c|}{ Yönetim } & \multicolumn{2}{|c|}{ Dnt.Krl. } & & \\
\hline & 1 & 2 & 3 & 4 & 5 & 6 & 7 & 8 & 9 & 10 & 11 & 12 & 13 & 14 & & \\
\hline OYAK yönetim faaliyetleri şeffaftır. & $\mathrm{x}$ & & $\mathrm{x}$ & $\mathrm{x}$ & & $\mathrm{x}$ & & $\mathrm{x}$ & $\mathrm{x}$ & & $\mathrm{x}$ & $\mathrm{x}$ & $\mathrm{x}$ & $\mathrm{x}$ & 10 & 71 \\
\hline OYAK, üyeleriyle iletişim sağlamaktadır. & $\mathrm{x}$ & $\mathrm{x}$ & $\mathrm{x}$ & $\mathrm{x}$ & $\mathrm{x}$ & $\mathrm{x}$ & & $\mathrm{x}$ & $\mathrm{x}$ & & $\mathrm{x}$ & $\mathrm{x}$ & $\mathrm{x}$ & $\mathrm{x}$ & 12 & 86 \\
\hline $\begin{array}{l}\text { OYAK yönetim/denetim faaliyetleri üyelere } \\
\text { hesap veren bir yapıya sahiptir. }\end{array}$ & $\mathrm{x}$ & & $\mathrm{x}$ & & $\mathrm{x}$ & $\mathrm{x}$ & $\mathrm{x}$ & $\mathrm{x}$ & $\mathrm{x}$ & & $\mathrm{x}$ & $\mathrm{x}$ & $\mathrm{x}$ & $\mathrm{x}$ & 11 & 78 \\
\hline $\begin{array}{l}\text { OYAK yönetim/denetim organlarına seçim } \\
\text { süreçleri yeterince etkindir. }\end{array}$ & $\mathrm{x}$ & & $\mathrm{x}$ & & $\mathrm{x}$ & & $\mathrm{X}$ & $\mathrm{x}$ & & & $\mathrm{x}$ & $\mathrm{x}$ & $\mathrm{x}$ & $\mathrm{x}$ & 9 & 64 \\
\hline $\begin{array}{l}\text { Bu görevlerdeki kişiler görevleri yeterli } \\
\text { etkinlikte yerine getirebiliyorlar. }\end{array}$ & $\mathrm{x}$ & & $\mathrm{x}$ & & $\mathrm{x}$ & & $\mathrm{X}$ & & $\mathrm{x}$ & $\mathrm{x}$ & $\mathrm{x}$ & $\mathrm{x}$ & & $\mathrm{x}$ & 9 & 64 \\
\hline Görevime yönelik bilgi ve tecrübeye sahibim. & & $\mathrm{x}$ & $\mathrm{x}$ & $\mathrm{x}$ & $\mathrm{x}$ & $\mathrm{x}$ & $\mathrm{x}$ & & $\mathrm{x}$ & & $\mathrm{x}$ & $\mathrm{x}$ & & $\mathrm{x}$ & 10 & 71 \\
\hline OYAK, etkin bir şekilde yönetiliyor. & $\mathrm{x}$ & & $\mathrm{x}$ & & $\mathrm{x}$ & $\mathrm{x}$ & & $\mathrm{x}$ & $\mathrm{x}$ & $\mathrm{x}$ & $\mathrm{x}$ & $\mathrm{x}$ & $\mathrm{x}$ & $\mathrm{x}$ & 11 & 78 \\
\hline OYAK mali kayıtları yeterince denetleniyor. & $\mathrm{x}$ & $\mathrm{x}$ & $\mathrm{x}$ & & $\mathrm{x}$ & $\mathrm{x}$ & & $\mathrm{x}$ & $\mathrm{x}$ & $\mathrm{x}$ & $\mathrm{x}$ & $\mathrm{x}$ & $\mathrm{x}$ & $\mathrm{x}$ & 12 & 86 \\
\hline
\end{tabular}

Y2... ve Denetim Kurulu üyeleri D1, D2 gibi). Katılımc1 görüssleri ve bu konudaki değerlendirmelerinden önemli betimlemeler aşağıdaki gibi oluşmuştur.

OYAK yönetim faaliyetlerinin şeffaflı̆̆ konusunda katılımcıların \% 71'i olumlu kanaate sahiptir. Özellikle Yönetim/Denetim Kurulu üyelerinin tamamı yönetimin şeffaf bir yapıda olduğuna inanmaktadır. Katılımcılardan D1'e göre; “OYAK denetim faaliyetleri profesyonelce yapılmaktadır. Özellikle uzman kurumların yaptığ denetimler şeffaflık için çok faydalıdır. " Y1 değerlendirmesini; "Görev yaptığım benzer başka yapılarda bu kadar şeffaf ve profesyonel yapılara rastlamadım, göreve başladığımda burada işlerin gerçekten sıkı denetlendiğini gördüm." şeklinde yapmıştır. Ancak G5; "OYAK'a ilişkin birçok bilgiyi Genel kurul üyesi olduktan sonra ögrendim. Aslında bu bilgilerin bir kısmı kurum internet sayfasında da varmış. Şeffaflık için bu sayfa daha etkin kullanılabilir." şeklinde yorum yaparken T5; "Kurum benzerlerine göre daha şeffaf ancak yine de daha fazla bilgi paylaşımı yapabilir." ifadesi ile şeffaflık yapısının geliştirilmesi gerektiğini belirtmişlerdir.

OYAK üye iletişimi konusunda katılımcıların olumlu değerlendirmeleri \% 86 ile en yüksek değere ulaşmıştır. Bu konuda G1; "İhtiyaç duyduğum tüm bilgileri kurumun internet sayfasından veya çă̆r merkezinden alabiliyorum." derken, Y1; "Faaliyetlerimizi üyelere anlatmak için her yolu deniyoruz. Ayrıca aldı̆̆ımız bilgiye göre üyeler bu kanalları çok etkin kullanıyor." demiştir. D2 ise; "Elbette ki tüm veriler üyelerle paylaşılır. Özellikle kendi kişisel menkulleri veya varlıkları. Ancak kabul etmek lazım ki OYAK ticari faaliyet icra etmekte ve bazl veriler ticari sir kapsamindadır ve paylaşılması doğru olmaz. ” yorumunu yapmıştır.

OYAK'ın hesap verebilirliği konusundaki soruya verilen olumlu cevap oran $1 \% 78$ seviyesindedir. $\mathrm{Bu}$ konuda Y2; "Yapısı gereğince kamuoyunda çok tartışıllr bir kurum olmak bizi benzerimiz yapllardan daha fazla olarak hesap vermeye itmiştir." demiştir. T3; "OYAK bana ve arkadaşlarıma verileri önceden gönderdi. Bilgimin yettiği kadarıyla inceledim. Şimdi arkadaşlarımla beraber incelemeye devam ediyoruz. Sorduğumuz tüm sorulara yönetimden cevap allyoruz. Bize sorduğumuz konularda hesap veriyorlar." demiştir.

Kurum yönetimine seçim süreçlerinin etkinliği ve bu görevlerdeki kişilerin görevleri yeterli etkinlikte yerine getirmeleri konularındaki sorulara verilen cevaplardaki genel olumluluk oranı \%64 ile görüşme konuları arasındaki en düşük oranda gerçekleşmiştir. Katılımcıların yaklaşık 2/3'ü bu süreci olumlu bulmakla birlikte özellikle Genel Kurul ve Temsilciler Kurulu üyelerinin bu konuda olumsuz bazı düşünceleri olduğu görülmüştür. Örneğin, T2; “Ben bu göreve seçildim ama burada belirtilen hususlart inceleyebilecek eğitime ve alt yapıya sahip değilim. Benim yerime bu konularda daha ehil birileri olsayd d daha iyi olurdu. " demiştir. G2; "Ben almış olduğum ĕgitimlerle Kurumun denetim faaliyetlerine katkl sağladığımı düşünüyorum. Zaten muhtemelen bu göreve de aldiğım hukuk ve iktisat ĕgitimimle seçildim." şeklinde bir yorum yapmıştır. 
Tablo 10: Kodlar ve Temalar

\begin{tabular}{|c|c|c|c|}
\hline Temalar & Kodlar & Sıklık & $\%$ \\
\hline \multirow{7}{*}{ Yönetimde asil vekil ilişkisi } & Profesyonellik & 9 & 12,85 \\
\hline & Yönetime güven & 8 & 11,42 \\
\hline & Vekil yetkinliği & 7 & 10.00 \\
\hline & Bilgi akış1 & 6 & 8,57 \\
\hline & Yasal mekanizmalar & 5 & 7,14 \\
\hline & Etkin yönetim & 5 & 7,14 \\
\hline & Geliştirilebilme & 3 & 4,28 \\
\hline \multirow{6}{*}{$\begin{array}{l}\text { Yönetimdeki vekâlet } \\
\text { sorunları }\end{array}$} & Bilgi asimetrisi & 9 & 12,85 \\
\hline & Vekil menfaatçiliği & 7 & 10,00 \\
\hline & Ön seçim hataları & 6 & 8,57 \\
\hline & Düşük performans & 5 & 7,14 \\
\hline & Yetersiz vekiller & 5 & 7,14 \\
\hline & İzleme zorluğu & 3 & 4,26 \\
\hline \multirow{9}{*}{$\begin{array}{l}\text { Vekâlet problemlerinin } \\
\text { çözüm tedbirleri }\end{array}$} & Şeffaflik & 11 & 15,71 \\
\hline & Hesap verebilirlik & 9 & 12,85 \\
\hline & Kontrol mekanizmaları & 8 & 11,42 \\
\hline & İzleme sistemleri & 6 & 8,57 \\
\hline & Derecelendirme kuruluşları & 3 & 4,28 \\
\hline & Profesyonel yönetim & 3 & 4,28 \\
\hline & Tarihsel yap1 & 2 & 2,85 \\
\hline & Mahkemeler & 2 & 2,85 \\
\hline & TBMM komisyonu & 2 & 2,85 \\
\hline \multirow{7}{*}{$\begin{array}{l}\text { Kurum yönetiminden } \\
\text { memnuniyet nedenleri. }\end{array}$} & Etkin yönetim & 11 & 15,71 \\
\hline & Başarı & 9 & 12,85 \\
\hline & Performans rakamları & 7 & 10,00 \\
\hline & Yüksek Nema & 7 & 10,00 \\
\hline & Şeffaf yap1 & 4 & 5,71 \\
\hline & İletişim sistemleri & 4 & 5,71 \\
\hline & Denetim sistemleri & 3 & 4,28 \\
\hline \multirow{8}{*}{ Şeffaflık ve hesap verebilirlik } & Vekillerin kontrolü & 11 & 15,71 \\
\hline & Caydırma & 8 & 11,42 \\
\hline & Yönetime güven & 8 & 11,42 \\
\hline & Bilgi sağlama & 7 & 10,00 \\
\hline & Yasal müeyyideler & 4 & 5,71 \\
\hline & Kanuni gereklilikler & 3 & 4,28 \\
\hline & İzleme imkânı & 2 & 2,85 \\
\hline & Bilgi asimetrisi & 2 & 2,85 \\
\hline
\end{tabular}

OYAK'1n etkin bir şekilde yönetilmesi konusundaki sorulara verilen olumlu cevap oranı \% 78'e ulaşmıştır. Bu konuda Y2; "Yönetimdeki şeffaflık ve hesap verebilirlik mekanizmalarl etkin yönetime katkı sağllyor." derken, T1; "Temsilciler Kurulu üyesi olduktan sonra kurum yönetiminin etkinliğini daha iyi gördüm. Önceden de bu yapllart duymuştum ama şimdi her bir kademenin şeffaflik, hesap verebilirlik ve etkin yönetim için ne kadar önemli olduğunu kendi gözlerimle gördüm." demiştir. D2; "Kendi mesleğim gereği birçok farkl yapıda denetim yapıyorum. Ancak şunu söyleyebilirim, OYAK yönetiminin etkinliği, hesap verme sistemleri etkin bir başarlya katkı sağllyor. Bunu şirket performans değerleri ve üyelere dağıtılan nemalarda da açıkça görebilirsiniz." demiştir.

Mali kayttların yeterince denetlenmesi konusunda görüşleri sorulan katılımcılar bu soruya \% 86 oranında olumlu cevap vermişlerdir. D1; "Ben Denetim Kurulu üyesi olarak yapmış olduğum denetim faaliyetlerinden memnunum. Eksik gördügümüz hususlar mutlaka oluyor, Yönetim Kurulu ve Genel Müdürlük eksik olarak raporladı̆̆ımı hususlara müdahale ederek 
düzeltiyor.” demiștir. Y2; “Ben hukuk yüksek lisans eğitimi almış birisi olarak bu yapı içerisinde icra ettiğim yönetim fonksiyonunda istediğim konularda denetim hakkımı kullanabiliyorum." yorumunu yapmıştır. T4; "Kayıtların bazılarına ticari sır gerekçesiyle ulaşamıyoruz. Bu denetimi kısıtlayan bir husustur." derken, G2; "Görev yapan bazı arkadaşlar mali denetimi yapacak yeteneğe sahip olmayabilir. Ayrıca bazı yönetim kararları veya dilek temenniler çeşitli gerekçelerle reddedilmektir. ” demiştir.

Elde edilen verilerle yazın taramasından çıarılan önemli kavramların yardımıyla temalar ve kodlar oluşturulmuş, yapılan mülakatta en çok bahsedilen kavramlar bulgular bölümünde tartışılmıştır. Çalışmanın, araştırma soruları temaların ve kodların belirlenmesinde temel hareket noktasını oluşturmuştur. Yazından geliştirilen bu sorular görüşme sürecinin açık ve kapalı uçlu sorularını da yönlendirmiştir. Katılımcılar kapalı uçlu sorularla vekâlet sorunlarına ve özellikle çalışmanın temel sorunsalı olan şeffaflık ve hesap verebilirlik mekanizmaları ile vekâlet kuramı ilişkisine yönlendirilmiştir. Bununla birlikte açık uçlu sorularla katılımcıların kendi görüş ve değerlendirmeleri de alınmaya çalışılmıştır. Hazırlanan temalar ve kodlar ile kodların görüşmeler sürecindeki ifade sıklığı Tablo-10'da sunulmuştur.

\subsubsection{Gözlem Bulguları}

OYAK yönetim faaliyetleri, 53. ve 55. Genel Kurullar ile 18. Temsilciler Kurulu toplantıları gözlemlenmiştir. Gözlem faaliyetleri genel olarak değerlendirildiğinde; Kurul üyeleri arasında etkin bir iletişim sistemi kurulduğu ancak Genel Kurul yasal üyeleri ile seçilen üyeleri arasındaki iletişimin belge taleplerinin kurum tarafindan karşılandığı ancak bir kısım bilgilerin ticari sır kapsamında olmaları gerekçesiyle sınırlı olarak paylaşıldığı, Genel Kurul üyelerinin vekiller adına yönetim kademesini denetledikleri, kullanılan en önemli aracın 'ibra' yetkisi olduğu görülmüştür.

Üyelerin denetim faaliyetlerini yerine getirmek için gerekli gayreti gösterdikleri ancak bir kısım üyenin kendilerini bu tür bir faaliyeti yerine getirebilecek yeteneklere sahip bulmadıkları görülmüştür. Üyelerin incelemek istedikleri tüm konularda araştırma yapma ve elde ettikleri sonuçları (övgü, eleştiri veya teklifler şeklinde) faaliyetlerin son günlerinde icra edilen toplantıda sunum olarak arz edebilme imkânları olduğu görülmüştür. Ayrıca tüm üyeler tartışılan konular hakkında görüş ve önerilerini herhangi bir ön kontrole tabi olmaksızın ifade edebilmişlerdir. $\mathrm{Bu}$ durum, OYAK yönetiminin vekil temsilcilerine yönelik bir hesap verme süreci olarak değerlendirilebilir. Temsilciler/Genel Kurul toplantılarının verbatim ${ }^{\mathrm{v}}$ metoduyla kayıt altına alınması ve OYAK dergisi sayılarıyla diğer üyeler ve kamuoyuyla paylaşılması da bir çeşit şeffaflık mekanizması olarak değerlendirilebilir.

Doküman analizi kapsamında OYAK internet sayfasında yapılan açıklamalar ile kamuoyuna ve üyelerine yönelik duyurularının analiz edilmesinin kurumun kendi bakış açısının görülmesi bakımından faydalı olacağı düşünülmüştür. $\mathrm{Bu}$ maksatla kurumun yönetim ilkeleri, hizmetleri ve prensipleri başlıkları altında yer alan duyuruları QDA Miner 4 programı ile analiz edilmiştir. Analiz sonuçları ve belirlenen tema ve kodların web sayfalarında geçme sıklığı Tablo-11'de özetlenmiştir.

Tablo 11: Kurum Web Sayfası Doküman Analizi (Kodlar ve Temalar)

\begin{tabular}{llccc}
\hline \multicolumn{1}{c}{ Tema } & \multicolumn{1}{c}{ Kod } & Tekrar Sayısı & $\begin{array}{c}\text { \%o } \\
\text { Kod }\end{array}$ & $\begin{array}{c}\text { Vaka } \\
\text { Sayısı }\end{array}$ \\
\hline Kurumsal Yönetim Yapısı & Genel Kurul & 4 & $6,20 \%$ & 2 \\
Kurumsal Yönetim Yapısı & Genel Müdür & 3 & $4,60 \%$ & 2 \\
Kurumsal Yönetim Yapısı & Temsilciler Kurulu & 3 & $4,60 \%$ & 2 \\
Kurumsal Yönetim Yapısı & Yönetim Kurulu & 5 & $7,70 \%$ & 3 \\
Kurumsal Yönetim Yapısı & Yönetim Etkinliği & 12 & $18,50 \%$ & 3 \\
Şeffaflık ve Hesap Verebilirlik & Şeffaflık & 10 & $15,40 \%$ & 2 \\
Şeffaflık ve Hesap Verebilirlik & Hizmet Kalitesi & 7 & $10,80 \%$ & 3 \\
Şeffaflık ve Hesap Verebilirlik & Güven Verme & 14 & $21,50 \%$ & 3 \\
Şeffaflık ve Hesap Verebilirlik & Üye İletişimi & 7 & $10,80 \%$ & 3 \\
\hline
\end{tabular}


Tablo 12: Genel Müdür Yıllık Mesajları Doküman Analizi (Kodlar ve Temalar)

\begin{tabular}{llccc}
\hline \multicolumn{1}{c}{ Tema } & \multicolumn{1}{c}{ Kod } & $\begin{array}{c}\text { Tekrar } \\
\text { Sayısı }\end{array}$ & $\begin{array}{c}\text { \%o } \\
\text { Kod }\end{array}$ & Vaka Sayısı \\
\hline OYAK Etkinliği & Büyüme & 27 & $15,60 \%$ & 3 \\
OYAK Etkinliği & Nema / kar paylaşımı & 18 & $10,40 \%$ & 3 \\
OYAK Etkinliği & Performans & 22 & $12,70 \%$ & 3 \\
OYAK Etkinliği & Sürdürülebilirlik & 27 & $15,60 \%$ & 3 \\
Yönetim Etkinliği & Yönetim Fonksiyonları & 19 & $11,00 \%$ & 3 \\
Yönetim Etkinliği & Profesyonellik & 20 & $11,60 \%$ & 3 \\
Yönetim Etkinliği & Şeffaflık/Hesap Verebilirlik & 9 & $5,20 \%$ & 3 \\
Yönetim Etkinliği & Yatırım Firsatları & 10 & $5,80 \%$ & 3 \\
Yönetim Etkinliği & Kurum Üye İletişimi & 5 & $2,90 \%$ & 3 \\
Yönetim Etkinliği & Üye memnuniyeti & 16 & $9,20 \%$ & 3 \\
\hline
\end{tabular}

Tablo 11'den de görüldüğü üzere kurum web sayfasindan üyelerine ve kamuoyuna kurumsal yönetim yapısı ile şeffaflık ve hesap verebilirlik sistemlerine ilişkin mesajlar vermektedir. Kurum tarafindan özellikle yürütülen hizmetlerde üyelerin güveninin kazanılması en çok tekrar edilen (14 tekrar ve \%21,5) kod olarak yer alırken bu kodu yönetim etkinliği (12 tekrar ve \%18,5) takip etmiştir. Şeffaflık kurum tarafindan en çok vurgulanan üçüncü husus (10 tekrar ve \%15,4) olarak yer almıştır. Kurum üye iletişimi ve hizmet kalitesi diğer önemli kodlar olarak (7 tekrar ve \%14,5) "Şeffaflık ve Hesap Verebilirlik" teması altında yer almıştır.

Doküman analizi kapsamında diğer bir analiz yöntemi olarak, yasal olarak OYAK'1 temsil etme yetkisine haiz olan OYAK Genel Müdürü'nün her yıl üyelere ve kamuoyuna web sayfasindan yayımlamış olduğu yıllık mesajlar incelenmiştir. Böylelikle kurum profesyonel yönetiminin en önemli organlarından birisi olan ve yatırımların geleceğine karar veren Genel Müdür'ün bakış açısı incelenmeye çalışılmıştır. Tablo-12'de görüldüğü üzere OYAK Genel Müdürü son üç ylllık mesajlarında kurum üyelerine ve kamuoyuna OYAK'ın performansı, sürdürülebilirlik politikaları büyüme hedefleri ve performans durumunu içeren ve 'OYAK'ın Etkinliği' teması altında kodlanan hususlara odaklanmıştır. Genel Müdür mesajlarında yönetim fonksiyonları, profesyonel yönetim, şeffaflık ve hesap verebilirlik, yatırım firsatlarının değerlendirilmesi, kurum üye iletişimi ve üye memnuniyeti başlıklarıyla kodlanan, 'OYAK Yönetim Etkinliği' teması altında toplanan konulara yoğunlaşmıştır. Genel Müdür 'OYAK'ın Etkinliği' teması altında özellikle büyüme ve sürdürülebilirlik konuları en çok tekrar edilen (27 tekrar ve \%15,6) kod olarak yer alırken bu kodu performans değerleri (22 tekrar ve \%12,7) takip etmiştirvi. Genel Müdür

vi İçerik analizinde sadece kelime sayısına bağlı olarak kelime analizi yapılmamıș, verilen mesajlara odaklanılmaya çalıșılmıștır. Araștırmada, sadece kelimelerin sayılması yerine mesaj içeriğinin tema ve kodlarla göre
OYAK Etkinliği teması konusu altında nema ve kâr paylaşımı koduna da (18 tekrar ve \% 10,4) önemli derecede vurgu yaptığ1 görülmüştür. OYAK Yönetim etkinliği konusunda Genel Müdür tarafindan en çok vurgulanan husus (20 tekrar ve \%11,6) yönetim faaliyetlerinin icrasındaki profesyonelliktir. Yönetim yapılarının etkinliği (19 tekrar ve \%11) ve üye memnuniyeti (16 tekrar ve $\% 9,2$ ) Genel Müdür tarafindan özellikle vurgu yapılan konulardır. Kurum yönetimindeki 'Şeffaflık ve Hesap Verebilirlik' teması Genel Müdür tarafindan kurum hedefi ve başarılarına katk1 sağlayan hususlar olarak vurgulanmıştır ( 9 tekrar ve $\% 5,2)$.

OYAK Genel Müdürü, üyelere kurumun sürdürülebilir performans değerleri konusunda bilgiler vermektedir. Vekiller ekibi içerisindeki diğer üyelere göre daha profesyonel bir bakış açısı ile tüm üyelere ve kamuoyuna ticari sir ilkelerini de göz önünde bulundurarak bilgi vermektedir. $\mathrm{Bu}$ durum hem hesap verme hem de şeffaflık bakış açısı ile yönetimin kendini ifade etme biçimi olarak yer almıştır. Bir holding olarak yönettiği kurumun başarılarına vurgu yaparken diğer yandan gelecek dönem yatırımlarına ilişkin değerlendirmelerini üyelerle ve kamuoyuyla paylaşmaktadır.

\section{TARTIŞMA VE SONUÇ}

Çalışmanın nicel ve nitel araştırma bölümlerinden elde edilen sonuçlar genel olarak değerlendirildiğinde kendine has bir yapısı olan OYAK'ta etkin, şeffaf ve hesap verebilir bir vekâlet yapısının kurulmaya çalışıldığı, vekâlet problemlerinin aşılmasında, şeffaflık ve hesap verebilirlik mekanizmalarının da etkin olduğu görülmüştür. Çalışmanın nicel bölümünde, genel olarak katılımcıların OYAK vekâlet yapısı, hizmet

tasnif edilmesi yöntemi kullanılmış ve raporlanma buna göre yapılmıştır. 
memnuniyeti, şeffaflık ve hesap verebilirlik sistemleri konusundaki algılarının pozitif yönde olduğu görülmüştür. Katılımcılar, OYAK'ın hesap verebilir bir yapıda olduğu ve yaptığ 1 faaliyetleri konusunda üyelere ve kamuoyuna hesap verdiğini değerlendirmişlerdir. Üyelere göre OYAK'ın şeffaflık yapısı da ortalamanın üzerindedir. Son değişken olan OYAK yönetim yapısının vekâlet etkinliği ise daha düşük seviyede yer almıştır. $\mathrm{Bu}$ durum, bir kısım üyenin OYAK yönetim etkinliği konusunda bazı şüphelere sahip olduğunu göstermiştir. Kuramsal bağlamda daha etkin bir asil-vekil ilişkisinin kurulmasının ve vekillerin asillere hesap verme mekanizmasının daha etkin hale getirilmesinin uygun olacağ 1 düşünülmektedir.

OYAK üyelerinin hizmetlerden ve kuruma üye olmaktan memnuniyetlerinin yüksek seviyede olduğu, ancak yeni üyelerin memnuniyet seviyesinin eski üyelere göre daha düşük seviyede olduğu görülmüştür. OYAK üyeliğinden memnuniyet, 20 yıldan fazla süredir kurum üyesi olan katılımcılarda en yüksek seviyeye çıkmaktadır. $\mathrm{Bu}$ durumun kuruma yeni üye olanların henüz bir fayda elde etmemiş olması, nispeten düşük olan gelirlerinden nema ödemesi yapıyor olmaları ve özellikle hayatlarının son dönemleri için önemli katkılar sağlayacak olan mesleki emeklilik fonuna genç dönemlerinde ödeme yapmaktan memnun olmamalarının neden olabileceği söylenebilir. Üyelerin, genel anlamda OYAK yönetim faaliyetlerinin şeffaf bir yapıda yürütüldügünü değerlendirdikleri görülmektedir. Ancak faaliyetlerin şeffaflığ 1 konusunda görevde olan üyelerin emekli olan üyelere göre daha yüksek bir algıya sahip oldukları görülmektedir. Araştırmaya katılan emekli personelde bu oran ortalama değerin altına düşmektedir. $\mathrm{Bu}$ sonuca göre emekli personelin kurum faaliyetlerinin şeffaf bir şekilde yürütülmediğini değerlendirdikleri görülmektedir.

Yönetim/denetim makamlarında görev yapanların OYAK yönetimine ilişkin genellikle olumlu değerlendirmeler yaptıkları görülmüştür. Ancak, Genel Kurul/Temsilciler Kurulunda görev yapan üyelerin verdikleri cevaplar Yönetim ve Denetim Kurulu üyelerinden daha az kesinlik ifade etmektedir. Özellikle "Yönetim/denetim organlarına seçim süreçlerinin etkinliği”" ve "bu görevlerdeki kişiler görevleri yeterli etkinlikte yerine getirebilmeleri" sorularına verilen olumlu cevaplar daha düşük seviyede kalmıştır. Bu nedenle Vekalet kuramı bağlamında özellikle profesyonellik konusunda sorun yaşandığı değerlendirmesinin yapılabileceği, yönetim ve denetim kademelerine vekil seçimlerinde profesyonellik seviyesi daha yüksek yöneticilerin seçilmesinin uygun olacağı düşünülmektedir.
Katılımcılara göre; "kurum, üyeleri ile gerekli iletişimi sağlamaktadır" ve "mali kaytlar yeterince denetlenmektedir. Diğer yandan, üyelerin bazılarının "Yönetim ve denetim organlarına seçim süreçlerinin etkinliğ $i$ " ve "bu görevlerdeki kişilerin görevleri yeterli etkinlikte yerine getirmeleri" konularında tereddütleri olduğu görülmüştür. Bazı üyeler kendilerini aldıkları görevi yerine getirebilecek bilgi ve tecrübeye sahip olmadıkları şekilde değerlendirmişlerdir. Yönetim kadrolarına seçilen bir kısım üye kurum yönetimi seçim sürecine olumsuz yaklaşmaktadır. Kurumun üyeleriyle etkin bir iletişim sistemi kurması ve faaliyetlerinin etkin denetimi kurum faaliyetleri bakımından bir başarı olarak görülebilir.

Gözlem faaliyetlerinde Temsilciler/Genel Kurul üyelerinin kendilerine sağlanan çalışma ortamında kurumun kayıt ve raporlarını inceledikleri görülmüştür. Ayrıca Genel Müdürlük ve Yönetim Kurulu tarafindan çalışma gruplarınca talep edilen bilgi ve belge isteklerine cevap verildiği, ancak üye olarak seçilen personelin bir kısmının inceleme yapılan konular hakkında yeterli bilgi ve tecrübeye sahip olmamaları nedeniyle zorlandıkları görülmüştür. Bazı üyeler de bir kısım yöneticilerin yeterli yetkinlikte olmadıkları doğrultusunda görüş belirtmişlerdir. Özellikle üye durumunda bulunan personelden yönetim ve denetim makamlarına personel seçiminde bazı aksaklıklar veya Kanun'dan kaynaklanan ön seçim hataları bulunmaktadır.

OYAK bir kısım çalışmalarda "bir başarı öyküsü" olarak (Alper vd., 2015; Petriçli vd., 2015) olarak görülürken bir kısım çalışmada "askerlerin holdingi" veya "ayrıcalıklı bir zümreye hizmet eden bir kuruluş" (Akça, 2010) olarak tanımlanmıştır. Bu çalışmaya katılan asil ve vekil üyelerin değerlendirmeleri ve kurumun elde ettiği performans değerleri ile üyelerine başlangıçta vaat edilenlerin önemli bir kısmını gerçekleştirdiği görülmüştür. Genel olarak üyelerin kurum hakkındaki değerlendirmelerinin olumlu olduğu ve kuruma üye olmaktan mutlu oldukları görülmüştür. Üyeler nezdinde OYAK şeffaf ve hesap verebilir bir yapıya sahiptir. Üyeler OYAK'a üye olmaktan memnun görünmektedirler. Alınan hizmetin kalitesinden memnuniyet ve vekâlet yapısına olan inanç yüksek seviyededir. Ancak OYAK'ın yazında belirtildiği gibi bir başarı hikâyesi olarak ifade edilmesinin de abartılı olacağı düşünülmektedir. Elde edilen performans değerleri nedeniyle kurumdan memnuniyet yüksek seviyede olmakla birlikte, kurumun yönetimine personel seçiminde bazı eksiklikler olduğu söylenebilir. Özellikle kuruluş dönemi itibariyle oluşturulan bazı yapılanmaların yönetim fonksiyonları bakımından sorunlar yaşanmasına neden olduğu da bir gerçektir. 
Kurumun kamuoyunda bazı kesimlerden eleştiri alması veya bazı davalara konu edilmesi de bu zorunlu yapının bir sonucudur.

Kurumun "yasal veya hukuki statüsü konusundaki belirsizlik" (Akça, 2010) benzeri emeklilik fonlarının birçoğunda da mevcut olan bir durumdur. $\mathrm{Bu}$ husus hem yargı kararlarında (AYİM, Yargitay ve Uyuşmazlık Mahkemesi gibi) hem de doktrinde (Y1lmaz, 1979; Y1lmaz, 1991; Gözler, 2009; Gözübüyük \& Tan, 2014) hâlen tartışmalı bir durumdur. $\mathrm{Bu}$ değerlendirmelerde Kurum'un hukuki anlamdaki melez yapısının etkisi önemlidir ve kurumun hukuki yapısı tartışmalıdır. Bir kısım mahkeme kararlarında kurum kamu hukuku tüzel kişisi olarak kabul edilirken, diğer bir kısım mahkeme kararlarında durumu tartışmalı olarak belirlenmiştir. Doktrinde de OYAK'1 kamu hukuku tüzel kişisi gören araştırmacılar var iken bazı araștırmacılar tarafından Kurum karma yapılı bir kişilik olarak görülmektedir.

Organizasyonlarda asiller tarafindan vekil tayin edilirken genellikle söz konusu vekillerin asiller adına yönetim faaliyetlerini icra ederken diğer yandan organizasyonun çevre ile güçlü bir bağ oluşturması amaçlanmaktadır. Yerel yazında yapılan benzer bir çalışmaya göre de asillerin vekil seçiminde tercihlerini emekli askerler, eski milletvekilleri, rakip firma çalışanları, güçlü ideolojik toplulukların üyeleri gibi aynı sosyal ağ düzeneği içerisinde bulunan diğer örgütlerin eski çalışanlarından yana kullandıkları, böylelikle belli bir sosyal ağ içerisinde aktif olan bir aktörün bu ağ 1 genişletmesi ve yeni sosyal ağlarla bağlantı kurmasının amaçlandığı ifade edilmektedir. Dolayısıyla ağsal merkeziliğin vekilin asili bağımlı hale getirmek için kullanabileceği en güçlü taktiklerden biri olabileceği ve bir aktörün bilgi birikimiyle elde edemeyeceği birçok faydayı kişisel ilişkileri yoluyla elde edebileceği değerlendirilmektedir (Dalğıran, 2014). Bu sonuçtan farklı olarak OYAK örneğinde bu seçim Kanun ile yapılmıştır. Yani kanunlaşma sürecinde kurum teşkil edilirken yönetim ve denetim organlarının görevlerini ifa etmek konusunda yeterli etkinlikte olması maksadıyla bu yapılara özel sektör ile sivil ve askeri bürokrasiden yöneticiler alınmaya çalışılmıştır. $\mathrm{Bu}$ yapının oluşturulmasında, Dalğıran'ın (2014) çalışmasında belirttiği gibi "sosyal ağ içerisindeki aktif aktörlerin kullanılması ve sosyal ağlarla bağ kurulmasından çok bu alanda zayıf olunmasından kaynaklanan kaygı" ön plandadır. Askerler tarafından teşkil edilen ve yönetilecek olan bu yapıya özellikle sivil iş adamları ve bürokratlar da alınarak piyasadaki gelişmelerden haberdar olunması, bir kısım ekonomi bürokratı ve denetmeni dâhil edilerek ise devletin denetim ve yönetim sistemleriyle yakın ilişki kurulması amaçlanmıştır.

Araştırma kapsamında, incelenen asil vekil ilişkisinin, vekâlet kuramı bakımından bazı farklılıklar ortaya koyduğu görülmüştür. Özellikle kendisi de kurum üyesi durumunda bulunanların yönetim faaliyetlerini etkin bir şekilde denetlemeye çalıştıkları görülmüştür. Ayrıca yönetim ve denetim mekanizmalarında homojen bir yapı yerine kabiliyet ve yetenekler dâhilinde heterojen yapıların oluşturulmasının denetim etkinliğine katkı sağladığ 1 değerlendirilmektedir. Sonuç olarak, organizasyonlarda oluşturulacak etkin denetim ve yönetim sistemlerinde paydaşların yer almasının vekâlet yapılarını güçlendireceği, hizmet kalitesini artıracağı, performans kriterlerini yükselteceği görülmektedir. Şeffaf ve hesap verebilir bir yapının oluşturulmasının, paydaşlar tarafindan denetim ve yönetim faaliyetlerine katılım sağlanan yönetim yapılarında vekâlet sorunlarının azalacağı, organizasyonel etkinliğin artacağ değerlendirilmektedir.

Sosyal beğenirlik etkisi sonuçların değerlendirilmesinde dikkate alınmalıdır. Araştırma sonucu elde edilen bulgular, verilerin toplanmasında kullanılan örnekleme göre değişiklik gösterebileceğinden çalışmanın bulguları, verilerin toplandığ 1 örneklem ile sinırlıdır. Bu nedenle farklı örneklemler için modelin test edilmesi gerekir. Ayrıca, nitel araştırma kapsamında elde edilen bulgulara yönelik değerlendirmeler, nitel araştırmaların yapısı gereğince araştırmacının yorumlarından doğrudan etkilenmektedir. $\mathrm{Bu}$ nedenle aynı değişkenler konusunda araştırma yapacak farklı araştırmacıların yorumları ve değerlendirmeleri farklılık gösterebilecektir.

Gelecek araştırmacılara öneriler kapsamında, vekâlet kuramının organizasyonlardaki uygulamalarına yönelik nicel ve nitel yöntemin birlikte kullanıldığı çalışmaya rastlanmamıştır. Ayrıca yöntem olarak yerel yazında çok sık rastlanmayan bir yöntem ile nicel ve nitel araştırma yöntemlerinin birlikte kullanıldığ çalışmanın gelecek dönem araştırmalarına metodolojik olarak katkı sağlayacağı ümit edilmektedir. Müteakip dönem çalışmalarında vekâlet ilişkisinin daha az sayıda sahibi bulunan ve kâr amacı güden organizasyonlar bağlamında da yapılması faydalı olacaktır. Ayrıca vekâlet problemlerinin bu çalışmada yeterince incelenmeyen boyutlarının da ayrıntılı olarak incelenmesinin faydalı olacağı düşünülmektedir. 


\section{KAYNAKÇA}

Akça, İ. (2010). Türkiye'de askeri-iktisadi yapı: Durum, sorunlar, çözümler. İstanbul, TESEV Yayınları.

Alper, Y, Arıcı, K., Özşuca, Ş.T., Aydın, U. \& Gökbayrak, Ş. (2015). Tamamlayıcı emeklilikte bir başarı öyküsü: OYAK. İstanbul: Türkiye İş Bankası Kültür Yayınları.

Dalğıran, Y. (2014). Asil-vekil ilişkisinde asilin körlüğü: Türkiye'de asil-vekil ilişkisinde vekilin sahip olduğu güce bağll olarak asilin tutumunun incelenmesi (Yayınlanmamış Yüksek Lisans Tezi). Ankara: Başkent Üniversitesi.

DeMott, D.A. (1998). A revised prospects for a third restatement of agency. U.C. Davis Law Review, 31, $1035-1063$

Eisenhardt, K.M. (1989), Agency theory: An assessment and review. Academy of Management Review, 14 (1), $57-74$.

Fama, E.F. (1980). Agency problems and the theory of the firm. Journal of Political Economy, 88, 288-307.

Fama, E.F. \& Jensen, M.C. (1983). Separation of ownership and control. Journal of Law and Economics, 26(2), 301-325.

Gözler, K. (2009). İdare hukuku, Cilt:1. Ankara: Ekin Basin Yayın,

Gözübüyük, A.Ş. \& Tan, T. (2014). İdare hukuku genel esaslar, Cilt:1, Ankara: Turhan Kitabevi.

Health, J. (2009). The uses and abuses of agency theory. Business Ethics Quarterly, 19 (4), 497-528.

Jensen, M.C. \& Meckling W.H. (1976). Theory of the firm: Managerial behavior, agency costs and ownership structure. Journal of Finance and Economy, 3, 305-360.

Jensen, M.C. (1983). Organization theory and methodology. Accounting Review, 58, 319-339.

Kiser, E. (1999). Comparing varieties of agency theory in economics, political science, and sociology: An illustration from state policy implementation. Sociology Theory, 17, 146-170.

Lan, L.L. \& Heracleous, L. (2010). Rethinking agency theory: The view from law. Academy of Management Review, 35, 294-314.

Meydan, C.H. \& Çetin, F. (2012). Örgüt kuramları. Sözen, H.C. \& Basım H.N. (Eds.), Vekâlet Kuramı, içinde. İstanbul: Beta Basım Yayın.

Mitnick, B.M. (1973). Fiduciary responsibility and public policy: The theory of agency and some consequences. Presented at Annual Meeting of American Political
Science Association, 69th, New Orleans.

Mitnick, B.M. (1992). Ethics and agency theory, N.E Bowie \& R.E Freeman (Eds.), The theory of agency and organizational analysis içinde. New York: Oxford University Press.

Nilakart, V. \& Rao, H. (1994). Agency theory and uncertainty in organizations: An evaluation. Organization Studies, 15 (5), 649-672.

Perrow, C. (1986). Complex organizations. (3rd edition). New York: Random House.

Petriçli, F., Bolatkale, F, Baskııı, M.M. \& Özsoy, O. (2015). Türkiye'nin özgün ve başarılı modeli: OYAK, 1961-1970, Cilt: 1, Kurtuluş, Ankara.

Ross, A.S. (1973). The Economic theory of agency principal problem. American Economy Review, 63, 134-139.

Shapiro, S.P. (2005). Agency theory. Annual Review of Sociology, 31 (1), 263-284.

Sharma, A. (1997). Professional as agent: Knowledge asymmetry in agency exchange. Academy of Management Review, 22 (1), 758-798.

Weber, M. (1924/1968). Economy and society: An Outline of Interpretive Sociology, G. Roth \& C. Wittich (Eds.), University of California Press, Berkeley, Los Angeles.

Yılmaz, E. (1979). Ordu yardımlaşma kurumunun hukuksal niteliği. Amme İdaresi Dergisi, 22 (1), 67.

Yılmaz, E. (1991), Ordu yardımlaşma kurumunun hukuksal yapısı. OYAK 30'ncu Yıl Özel Sayısı, OYAK Yayınları, 48-51.

Zajac, E.J. \& Westphal, J.D. (2004). The social construction of market value: Institutionalization and learning perspectives on stock market reactions. American Sociology Review, 69 (3), 233-257. 